\title{
Tegelsten nummer två
}

\author{
Recension av Thomas Piketty, Kapitalet och ideologin \\ (Mondial, Stockholm 2020)
}

\section{JONNY HJELM}

Med boken Kapitalet i tjugoforsta århundradet (2013, på svenska 2015) fick den franske nationalekonomen Thomas Piketty internationell ryktbar status och kallades vår tids Karl Marx. Många minns kanske hans besök hos Skavlan 2017 där han frejdigt diskuterade skattepolitik med Norwegians vd Bjørn Kjos.

I boken visades på den kraftigt ökande ojämlikhet som ägt rum efter 1980. I land efter land har de rikaste tio procenten kraftigt ökat sina inkomster och förmögenheter. Några av orsakerna som pekades ut var de återkommande skattesänkningarna samt finanssektorns avreglering. Bokens genomslag och politiska sprängkraft berodde bland annat på att den kom i spåren på 2008 års finanskris som allvarligt skadat förtroendet för kapitalismen.

I Pikettys uppföljare Kapitalet och ideologin (2019, på svenska 2020) är syftet inte enbart att visa på ojämlikheten idag och tidigare i historien, utan också att förklara hur ojämlikhet ideologiskt har förklarats och legitimerats. Pikettys utgångspunkt är att det i varje samhälle finns en förklaring - eller en uppsättning förklaringar - till att vissa är superrika och andra lever i armod, och varför detta är en acceptabel sambällsordning. Piketty betonar ideologins betydelse som ojämlikhetsupphållare och är kritisk till den strömning inom den marxistiska eller historiematerialistiska traditionen som beskriver den ideologiska "överbyggnaden" som entydigt bestämd av produktionsformerna och de ekonomiska 
krafterna. "I motsats till detta synsätt insisterar jag på att idéernas rike, den politisk-ideologiska sfären, är något fullständigt autonomt.”

I Kapitalet och ideologin behandlar Piketty de sex ojämlikhetsideologiska tankesystem eller samhällen som enligt honom funnits i mänsklighetens historia och vad som karaktäriserat dessa: det trifunktionella samhället, ägarsamhället och det socialdemokratiska samhället, samt de som delvis funnits före men också parallellt i tid, de slavbaserade, koloniala och kommunistiska samhällena (de sistnämnda kan jag av utrymmesskäl inte behandla här). Större delen av boken ägnas beskrivningar och analyser av dessa samhällen baserade på många olika källor, exempelvis nationalräkenskaper, uppgifter rörande skatter, vallokalsundersökningar och World Inequality Database.

Ett viktigt inslag i Pikettys bok är jämförelser, över tid men också jämförelser mellan länder, regioner och världsdelar. Syftet är primärt att visa hur tids- och samhällskontextberoende olika ojämlikhetssystem är, och även hur stora faktiskt skillnaderna är. I en redovisning av "globala ojämlikhetssystem" visas exempelvis att Mellanöstern är i särklass mest ojämlikt (med Qatar som det mest extrema exemplet). I de flesta av dessa jämförelser framstår Europa (och Sverige som han visar särskilt intresse) som den minst ojämlika världsdelen.

Historiskt sett dominerade länge det som Piketty kallar "trifunktionella” samhällen. I dessa samhällen fanns längst ned den arbetande klassen (bönder, arbetare), som ovanför sig hade en krigaradel med våldsmonopol som maktrelationellt balanserades av en mäktig prästklass. De trifunktionella samhällena förlitade sig på relativt stabila statusskillnader och tankar om treenighetens funktionella komplementaritet. Alla hade sin särskilda plats. Om krigaradeln blev för stark och ensidigt värdsligt auktoritär hotades den samhälleliga stabiliteten. Motkraften var alltså prästklassen, det trifunktionella samhällets ideologiproducenter. Deras uppgift var att förklara och legitimera den samhälleliga ordningen och ojämlikheten; att den var en del av den gudomliga ordningen. Men en allt för stark och månghövdad prästklass hotade även den trifunktionella samhällsordningen; de skulle ju försörjas av den arbetande klassen (detta underbyggs bland annat med siffror som visar att uppemot 3-5 procent av vuxna män var präster i I60o-talets Spanien, Frankrike och Storbritannien). 
Det trifunktionella samhället avlöstes enligt Piketty under I8oo- och I900-talen av "ägarsamhället" och en ideologi som vilade på löfte om social stabilitet knuten till individuell emancipation genom den privata äganderätten; öppen för alla oberoende av socialt ursprung. Det trifunktionella samhällets statusfixering, kopplad till börd och släkter avklingade till förmån för ett mer meritokratiskt ideal.

Ojämlikt utfall i ekonomiskt hänseende, att en del individer fick högre lön och med tiden stora förmögenheter, legitimerades i ägarsamhället med att det var en rättvis belöning för de ansträngningar som gjorts och sammantaget var för det allmännas bästa. I de mer utvecklade ägarsamhällena infann sig dock betydande problem i början av I900-talet, bland annat genom en mäktig anhopning av förmögenheter - Piketty visar med siffror på den extrema förmögenhetsojämlikheten i Frankrike, Storbritannien och Sverige under la belle époque (I880-1914) som var svåra att rättfärdiga ideologiskt och skapade sociala spänningar. Ett annat problem, som också det hotade undergräva den ideologiska överbyggnaden, var att ägarsamhällenas exploatering av kolonier runt om i världen på allvar började ifrågasättas. Motståndet utvecklades i såväl kolonierna av de underkuvade som av progressiva politiska krafter i kolonialmakterna. Ett tredje problem var ägarsamhällenas nationalistiska karaktär - de nationella institutionerna stod för äganderättsskydd och främjande av ekonomisk utveckling - och att detta tillsammans med utvecklingen av identitetsrelaterade "folk"-dimensioner understödde en destruktiv utveckling och konkurrens om kolonier och marknader som kom att leda till två världskrig.

Sverige är ett av de länder som Piketty tar upp närmare när de socialdemokratiska samhällena behandlas. Dessa samhällen växte fram som en reaktion på, och som en motkraft till, ägarsamhällenas ojämlikhetsskapande konsekvenser och nådde sin höjdpunkt ca 1950-I980. I land efter land erövrades den politiska makten av partier som Piketty kallar "socialdemokratiska" - även om de nationellt kunde heta något annat - och genomdrev en blandning av politiska åtgärder inklusive nationaliseringar, offentligfinansierade utbildnings-, hälso-, sjukvårds- och pensionsreformer. Utöver detta karaktäriserades dessa samhällen också av en progressiv beskattning av de högsta inkomsterna och största 
förmögenheterna. Politiska åtgärder som länge uppfattats som helt orimliga, ja, rent av onaturliga och samhällsfarliga, hade på grund av världskrigens förödelser, mellankrigsdecenniernas ekonomiska kriser och genom politisk-strategisk verksamhet inom den reformistiska vänstern genomförts förhållandevis konfliktfritt och utan att samhällen drabbades av anarki, laglöshet och utbredd lättja.

Extra intressant är Pikettys analys av väljarkårerna i USA och i västeuropeiska länder under efterkrigsdecennierna, där han visar att överklassens kulturella (till exempel högutbildade) och "merkantila" fraktioner kring 1950 utomordentligt sällan stödde socialdemokratiska partier vilket dock arbetarklassens kärntrupper gjorde. Detta hade dock ändrat sig 1990. Med stöd i länderspecifika data visar Piketty hur det skett en omkastning där den välutbildade kulturella delen av överklassen i allt högre grad börjat stödja socialdemokratiska partier (den merkantila fraktionen fortsätter i sitt icke-stöd) medan icke-privilegierade grupper inom arbetarklassen i ökad utsträckning övergett de socialdemokratiska partierna och istället föredrog partier som ville se en återgång till den ägarrättsliga samhällstypen eller partier med en konservativt baserad identitetspolitisk, nationalistisk agenda.

Från och med 1970-talet utmanades de socialdemokratiska samhällena av det som Piketty benämner neoägarsamhället. Det rörde sig om en världsomspännande variant av de ägarrättsliga samhällen som dominerade i början av I90o-talet. Det neoägarrättsliga samhället präglas av hyperkapitalismens globaliserade ekonomiska flödesströmningar medan de politiska krafterna i allt väsentligt fortfarande var (är) nationalistiskt inriktade. Nationellt verkande politiker, oavsett politisk färg, började underbjuda varandra i hopp om att attrahera multinationella företag och de förmögna som antogs kunna skapa nya arbetstillfällen.

Piketty är både uppfordrande och kritisk till I970-1980-talens vänsterpolitiska aktörer som inte klarade utmaningen från neoägarsamhällets förespråkare. Socialdemokrater som de svenska beskrivs som politisktvisionärt begränsade och alltför nationellt präglade (men också till vissa delar splittrade då välutbildade socialdemokrater hade en obekymrat kosmopolitisk orientering som låg nära den merkantila delen av överklassen). Han är ännu mer kritisk mot kommunistpartier och deras aktivister 
som på ett intellektuellt och politiskt-strategiskt slött och oengagerat sätt tänkt sig realiserandet av ett rättvist jämlikt samhälle med höjda skatter (oavsett hur skatter av skilda slag slår mot olika grupper) och förstatligandet av företag utan att konkretisera hur detta skulle gå till. De kommunistiska regimerna, som Piketty inte har mycket gott att säga om, och kalla krigets polarisering försvårade givetvis också alla försök till progressivt, rättvisepräglat experimentellt tänkande. Vår tids identitära rörelser ("den här nya identitära sjukan") - "social nativism" som de kallas av Piketty avvisas också som i grunden konservativa och oförmögna att bygga breda och reellt kraftfulla transnationella rättvisepolitiska allianser.

I Kapitalet och ideologins avslutande delar presenteras en skiss över hur ett jämlikt samhälle skulle kunna se ut. I detta samhälle - "deltagande socialism" som Piketty kallar det - finns världen över federala demokratiska arrangemang som fungerar som politiska motvikter till den fria företagsamheten. Människor kommer fortfarande, som idag, att leva på olika sätt och ha olika preferenser, men politiken kommer att ha som mål att organisera samhället så att de minst gynnade medlemmarna ges tillgång till de bästa möjliga levnadsvillkoren. Skatterna kommer att ligga på nivåer som inte torde tilltala medlemmarna i Skattebetalarnas förening.

\section{es}

Frågan om ojämlikhet, och hur dylikt legitimeras ideologiskt, är givetvis inget nytt tema inom vetenskapen, än mindre inom den politiska sfären. Det speciella med Pikettys nya bok är dels hans starka empiriska förankring i ojämlikhetsdata av skilda slag och från olika länder och världsdelar och tidsperioder, dels hans förmåga att växla mellan ett abstrakt teoretiserande om olika samhällens ojämlikhetssystem och hur dessa konkret kan yttra sig i all sin komplexa mångfald.

Pikettys aktörsorienterade ansats, och återkommande utförliga kontextualiseringar, ger framställningen en spännande dynamik, men är också ett uttryck för hans syn på historien som en individuell och kollektiv läroprocess. Alla folkgemenskaper är enligt Piketty bärare av erfarenheter, men det gäller också institutioner, lagstiftning, intellektuella traditioner etcetera, och då och då infinner sig i dessa länders "banor" 
ökade handlingsutrymmen, ibland orsakade av sådant som revolutioner, världskrig eller våldsamma socioekonomiska sammanbrott, då rättviseförespråkande politiska aktörer har möjlighet att realisera sina politiska idéer. Ett exempel är genomförandet av Roosevelts New Deal-politik i USA som inkluderade förhållandevis höga marginalskatter. Enligt Piketty baserades denna politik till viss del på de frihetliga och meritokratiska ideal som hyllades med rötter i I70o-talets självständighetskamp och upplysningsidéer.

Bokens största svaghet är dess idealistiska slagsida vilket framträder särskilt skarpt i hans analys av neoägarsamhällets genomslag kring 1980, som förklaras med att de som skulle försvara de socialdemokratiska samhällenas skattenivåer och politik i övrigt inte var tillräckligt engagerade och nytänkande. Förklaringen övertygar inte. Socialdemokraternas oförmåga eller ovilja att tänka utanför den nationella "boxen" bör - och i enlighet med Pikettys betoning av de historiska erfarenheternas betydelse - till betydande del bero på att nationen under I800- och 1900-talen var den politiska huvudarenan, och att det länge fungerat tämligen bra. Det finns också en tendens, vanlig hos dem som arbetar med historiens långa utvecklingslinjer, att bunta ihop det som ligger långt tillbaka i tid (de trifunktionella samhällena har funnits i tiotusentals år), men att differentiera det som ligger närmare oss i tid (de övriga fem ojämlikhetslegitimerande samhällstyper som Piketty uppmärksammar finns, eller har funnits, delvis parallellt med varandra, de senaste 200 åren). En slags historisk närsynthet, skulle man kunna kalla det. Att de socialdemokratiska samhällena verkligen skulle utgöra ett särskilt samhällssystem av samma dignitet som det ägarrättsliga sätter jag vidare frågetecken för. Jag blir inte heller klar över neoägarsamhället; om det ska ses som något helt nytt, eller som en version av det gamla ägarrättsliga samhällssystemet.

Sammantaget är Kapitalet och ideologin en intressant bok som inte väjer för de stora frågorna och historiens långa utveckling. Styrkan ligger främst i beskrivningarna av ojämlikhetssystemen och de stöd dessa har i presenterade data, i mindre grad i de förklaringar som ges till varför dessa ojämlikhetssystem existerat och existerar. I jämförelse med den föregående boken är det eurocentriska perspektivet mindre framträdande, och nu behandlas också de miljömässiga utmaningarna som mänskligheten 
ska hantera. Piketty har också en sedvanlig fransk akademisk förmåga att oförväget och med friskt humör lansera nya begrepp och resonemang. Beläsenheten och tvärvetenskapligheten imponerar. Språket är närmast populärvetenskapligt, vilket underlättar läsningen av de I 200 sidorna. Boken refereras redan flitigt av de som världen över önskar se ökad jämlikhet och mer överstatligt samarbete. Intresset och det överlag positiva mottagandet boken fått i särskilt (radikala) socialdemokratiska kretsar i Sverige är inte svår att förstå. Men visst borde också denna bok, som den förra, ges ut i en kortfattad version. Inte många har praktiska möjligheter att läsa tegelstenar av detta slag. 


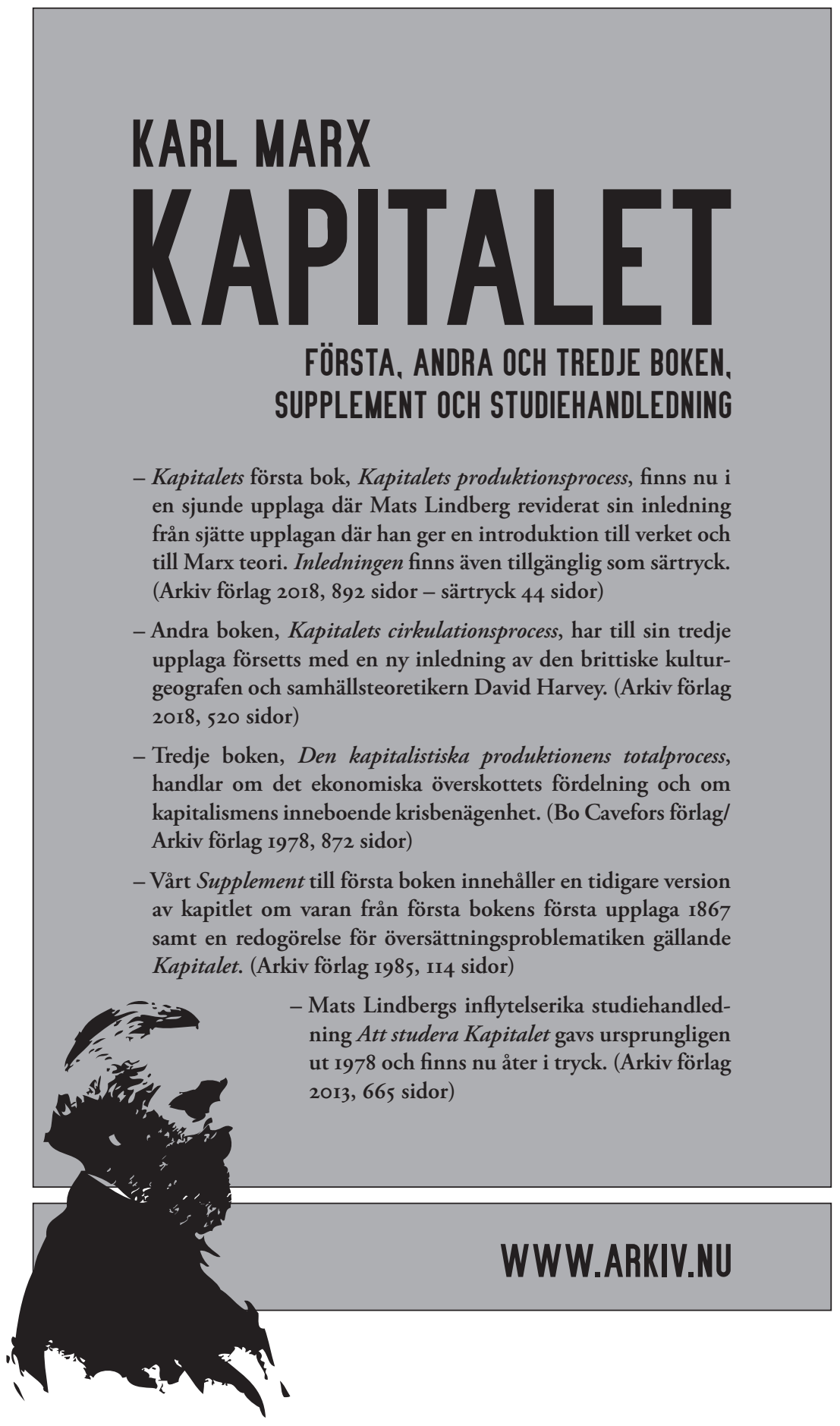

